\title{
IMPROVEMENT OF ORGANIZATIONAL AND ECONOMIC, HUMANITARIAN AND OTHER MECHANISMS OF FORMATION OF ENTREPRENEURSHIP CULTURE AND PERSONALITY
}

\author{
Cherep A. V., Andrushkiv B. M., Sherstiuk R. P., Melnyk L. M. \\ Zaporizhzhia National University \\ Ukraine, 69600, Zaporizhzhia, Zhukovsky str., 66 \\ cherep.av.znu@gmail.com \\ ORCID 0000-0001-5253-7481
}

Key words:

management, corporate ethics, corporate culture, leader, manager, efficiency, enterprise, entrepreneurship, spirituality, morality.
The article is devoted to the study of features and disclosure of ways of development of morality and Christian virtues in the formation of the personality of modern society. The content of spirituality and certain moral traits, man and society is characterized. It is proposed to contrast the development of negative manifestations of personality in modern society, its aggressive characteristics, and morality and eternal Christian values. With the growth of negative information on the Internet and the media, help a person find himself on the basis of Christian morality. It is proposed to improve the organizational, economic and humanitarian mechanisms, to achieve positive changes through the involvement of moral values, which we are told by the Holy Scriptures - the Bible. It is established that in practice some features are popularized more widely and others less by information means. Due to these circumstances, some features appear more often and last longer, others appear less often. It is confirmed that the Christian virtues Faith, Hope and Love are the basis of spiritual and moral education of the individual. The article will help civil servants, businessmen-entrepreneurs not only in the process of forming corporate culture, but also in the process of improving organizational and economic, humanitarian and other mechanisms of forming the culture of entrepreneurship and personality in society.

\section{УДОСКОНАЛЕННЯ ОРГАНІЗАЦИИНО-ЕКОНОМІЧНИХ, ГУМАНІТАРНИХ ТА ІНШИХ МЕХАНІЗМІВ ФОРМУВАННЯ КУЛЬТУРИ ПІДПРИСМНИЦТВА ТА ОСОБИСТОСТІ}

\author{
Череп А. В., Андрушків Б. М., Шерстюк Р. П., Мельник Л. М. \\ Запорізький національний університет \\ Украӥна, 69600, м. Запоріжжя, вул. Жуковського, 66
}

\section{Ключові слова:}

управління, корпоративна етика, корпоративна культура, керівник, менеджер, ефективність, підприємство, підприємництво, духовність, моральність.

\begin{abstract}
Стаття присвячена вивченню особливостей та розкриттю шляхів розвитку моральності і християнських чеснот у формуванні особистості сучасного суспільства. Охарактеризовано зміст духовності та окремих моральних рис, людини та суспільства. Запропоновано протиставити розвиток негативних проявів особистості в сучасному суспільстві, його агресивних характеристик, моральність та вічні християнські цінності. В умовах зростання негативної інформації в Інтернеті та 3МІ, допомогти особі віднайти себе на засадах християнської моралі. Запропоновано удосконалення організаційно-економічних та гуманітарних механізмів, досягнення позитивних зрушень за рахунок залучення моральних цінностей, про які нам говорить Святе Письмо - Біблія. Встановлено той факт, що на практиці інформаційними засобами одні риси популяризуються ширше, а інші менше. В силу згаданих обставин, одні риси проявляються частіше i тривають довше, інші проявляються рідше. Встановлено, що в основу духовно-морального виховання особистості покладені християнські чесноти Віра, Надія і Любов. Стаття допоможе державним службовцям, бізнесменампідприємцям не тільки в процесі формування корпоративної культури, а i в процесі удосконалення організаційно-економічних, гуманітарних та інших механізмів формування культури підприємництва та особистості у суспільстві.
\end{abstract}

\section{Formulation of the problem}

The subject of industrial culture, corporate ethics as a phenomenon has long been not only part of the philosophy of large multinational, international corporations or other large companies, but also a component of national culture. At the same time the problems of researching features and ways of developing Christian virtues in shaping the personality of modern post-totalitarian society, with culture of entrepreneurship or corporate ethics as a means of its education on a national scale, require the involvement of all factors, including moral and spiritual, it is evidenced by the speeches of members of the discussion club: "Problems of development of spirituality, culture and morality in a post-totalitarian society", and is shown by sociological surveys. As you know, corporate 
culture is the basis for the formation of interpersonal relationships of employees (understand in the workplace) and is not a comprehensive tool for shaping the personality of modern post-totalitarian society, which would take into account the action of spiritual and moral factors. Many managers are skeptical, but in reality the use of spiritual and moral rules of conduct is quite effective, despite the fact that it is also based on generally accepted ethics and legislation. For example, the effectiveness of corporate ethics seems to have been repeatedly proven by international and Ukrainian companies, at the same time, due to the instability of the spiritual component in the educational process, is often violated. Thus, efficiency is achieved, first of all, not only due to the cohesion of employees, as the main asset of any enterprise, but largely the strength of moral and spiritual beliefs. In addition to "corporate culture", the spread of Christian virtues in shaping the personality of modern post-totalitarian society in many crises, war, in today's conditions is a necessary and extremely important phenomenon, as it creates in workers not only a sense of purity, insight, but also the need for internal change. Actually, these and other circumstances determine the relevance and timeliness of the topic of the article.

\section{Analysis of recent research}

The following Ukrainian scientists in their works have studied the peculiarities of the development of corporate culture as a factor and tool for improving the efficiency of production and a means of forming a successful businessman and the development of entrepreneurship. They are: O. Apostoliuk, O. Bala, I. Bekh, G. Bulashev, G. Vashchenko, D. Thordzhevskii, O. Duke, M. Dmytrenko, V. Zelich, V. Kozlov, O. Kyslashko, N. Polishchuk, A. Polianska, I. Sidanych, S. Snigur, V. Semenenko, M. Stelmakhovych, O. Tarasova, T. Chernyshova, K. Yarosh, others. [1 - 19].

Many of these experts agree that corporate culture and ethics should be formed based on the production environment, unite and form the educational foundations of employees in general. Meanwhile, the study of features and ways of moral development, Christian virtues in shaping the personality of modern post-totalitarian society, taking into account the achievements of corporate culture, business culture or corporate ethics as a means of its education remained out of sight of domestic scientists. This allowed us to formulate the purpose and objectives of this study.

\section{The purpose and objectives of the article}

Thus, the aim of the article is to reveal the features and ways of development of morality, Christian virtues in the formation of the culture of the individual of modern, posttotalitarian society. It is the search for ways to improve the culture of entrepreneurship, the using the principles of corporate ethics as a tool for integrated education of the culture of the individual and the modern entrepreneur. The objectives of the article are to clarify certain concepts related to the research topic, to consider the theoretical foundations and applied principles of forming the personality culture of modern post-totalitarian society, taking into account the impact on these processes.

\section{Statement of the main provisions of the article}

Consideration of such a topical and delicate topic is not possible without covering the results of sociological research, highlighting the conclusions and the most acute moments of the discussion club: "Problems of development of spirituality, culture and morality in a posttotalitarian society".

The formation of the personality of the post-totalitarian space can effectively take place in two main ways: the introduction of managers "corporate culture", which provides an understanding of the importance of himself, not only as an employee at a much higher level, as a team member, a living part of the company, and a deep understanding of his place and the work performed. Undoubtedly, in such conditions, the employee will show much better results, compared to creating a comfortable environment. However, with the presence of the spiritual and moral components of this process, the indicators can be meaningful and therefore much higher, while the individual receives moral satisfaction from the realization of the duty.

The algorithm for improving organizational, economic, humanitarian and other mechanisms of formation of the personality of post-totalitarian society is shown in Fig.1.

In fact, it should be noted that in Ukraine after the totalitarian period there is a crisis of sensible, capable of sacrificing spiritual leaders, and in particular in public administration. From the standpoint of self-criticism, it must be acknowledged that at present there is a new generation of Ukrainian managers who are rather the exception to the rule. After all, for example, civilized European and American schools of management have passed the stages of formation, and Ukrainian entrepreneurs are just passing it. At the same time, this is happening in conditions of numerous crises and war in the East. 


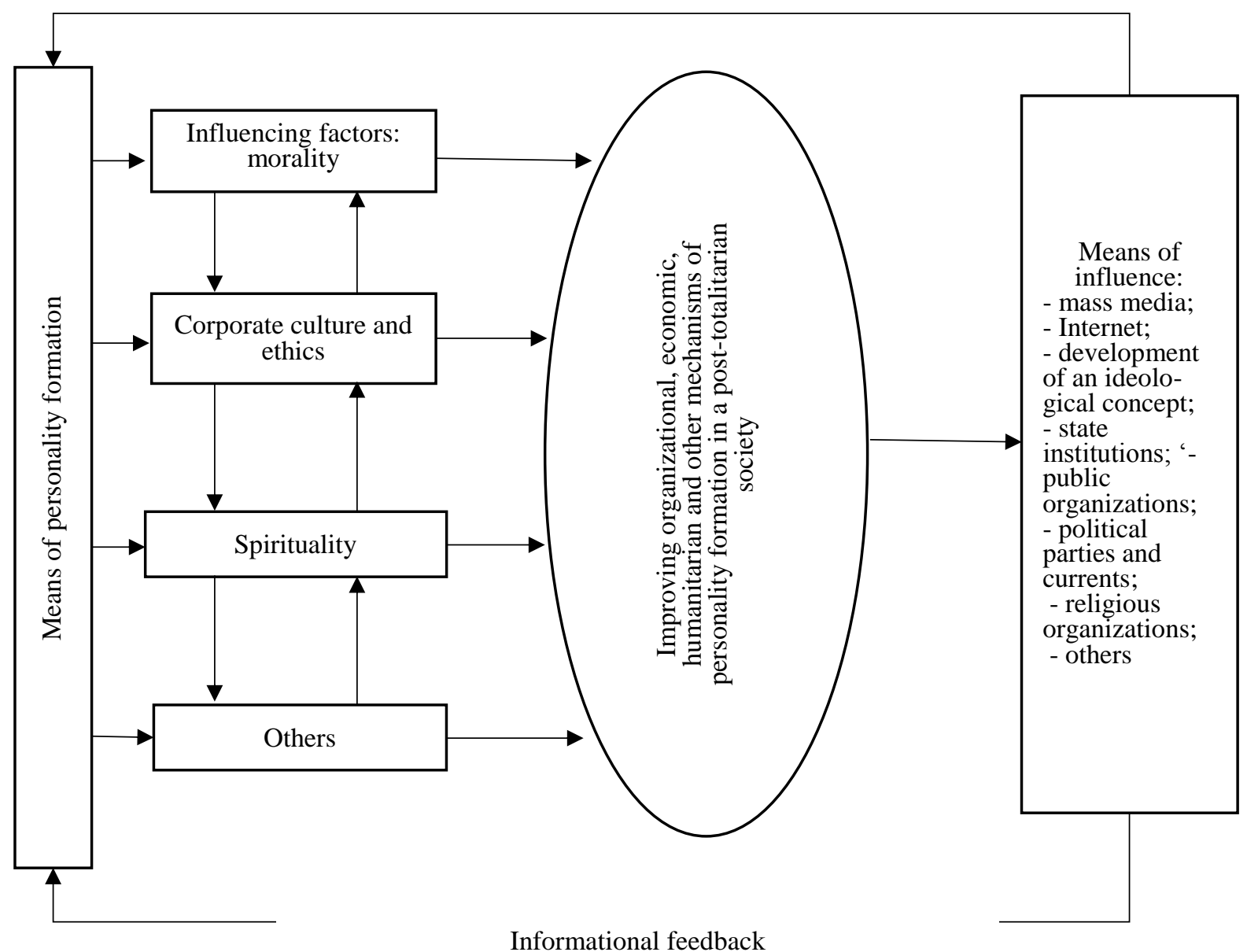

Fig.1. Algorithm for improving organizational, economic, humanitarian and other mechanisms of personality formation in a post-totalitarian society

\section{Conclusions}

Thus, the main ideologue of corporate culture is the head or owner of the business. Because who but he should see the perspective, the picture of the company's development, and must form the corporate ethics from which its achievements flow based on its purpose and purpose. Based on the described conclusions, it is necessary to give an explanation of who and what properties characterize the personality of a modern successful manager, among which is society with its institutions of an ideological and spiritual nature.

Undoubtedly, corporate culture includes at least two professional competence and personal qualities. Literature sources $[1,4,5-15,19]$ indicate that there are many more of them. In particular, motivation, openness, desire to learn... and so on. The formation and development of personality should provide a balance of characteristics. One of them is the desire to learn in the process of work. "Corporate culture", "ethics of relationships", etc., which today are an attribute of the company, which cares about the image, business reputation primarily within the organization, and outside it. In essence, the culture of the individual in Ukraine is a kind of set of stereotypes of behavior and actions which is transferred from the era of post-totalitarian regime, command economy, devoid of spirituality, morality, humanism. At present, these features can be borrowed from the Western experience, that consists of business culture and "rules of the game", which now need to be adapted in the newly created corporations of the posttotalitarian regime. The task of today is discovering the features and ways of development of morality, Christian virtues in the formation of the personality of modern society. The study of the content of certain spiritual and other moral traits that dominate in man and in society must be implemented in a balanced way in public life. At present, it is advisable to improve organizational and economic mechanisms so that the implementation of each creative idea resists the development of negative manifestations in the development of personality, helps to suppress its aggressive characteristics and strengthen morality, and use factors of eternal Christian virtues and values.

\section{References}

1. Apostoliuk O.Z. Corporate culture as a tool for effective management of the enterprise in increasing its competitiveness. Economic Journal of Lesia Ukrainka East European National University. 2016. № 2. P. 68-73.

2. Bible / translated by Ogienko I. Donetsk: OBF "Eastern European Humanitarian Mission", 2015. 1360 p. 
3. Helley Henry's Bible Handbook. World Christian Mission, 1985. - 856 p.

4. Bekh I.D. Education of personality: in 2 books. Sq. 1: Personality-oriented approach: theoretical and technical principles: teaching method edition. $\mathrm{K}$.: Lybid, 2003. - $280 \mathrm{p}$.

5. Biblical principles of life and ministry / Leonid Yakobchuk. Ostrog, 2008. - 576 p.

6. Bulashev G. Ukrainian people in their legends, religious views. K .: Dovira, 1993. - 444 p.

7. Vashchenko G.G. Works on pedagogy and psychology in 4 vols. K .: Schoolboy; Fada LTD, 2000. T. 4. - 415 p.

8. Large explanatory dictionary of the modern Ukrainian language / Emphasis. and heads. ed. W. G. Busel. K .: Irpin, VTF "Perun", 2003. - 1140 p.

9. Education of the young generation on the principles of Christian morality in the process of spiritual revival of Ukraine: scientific notes: collection of scientific works. Ostrog, 2000. T. 3. - 633 p.

10. Education of nationally conscious personality: method. manual/ Ed. D.O. Thorzhevskii. Glukhiv: RVVGDPI, 2001. $148 \mathrm{p}$.

11. Kyslashko O.P., Iryna S.L. "Christian virtues of personality" (approved for use in secondary schools by the Ministry of Education and Science of Ukraine (Minutes №1 of May 10, 2017) K. Spiritual Axis, 2017 - 448 p.

12. Corporate ethics. URL: http://www.naftogaz.com/www/3/ nakweb.nsf / 0 / CD039B50EA1ACF46C2257E89002 F0648? OpenDocument \& Expand $=4$ \&i

13. Polianska A.S., Duke O.M. Formation of a model of corporate culture in the activities of domestic enterprises. Economics and business management. 2018 № 27. - P.10.

14. Snigur S.A. Functioning of moral values of Christianity in the culture of Kievan Rus: dissertation. Philos. Science. K. 2004. - 174 p.

15. Stelmakhovych M.G. Theory and practice of Ukrainian national education. Ivano-Frankivsk, 1996. - 50 p.

16. Stelmakhovych M.G. Ukrainian folk pedagogy: teaching method. Manual. K: TZMN, 1997. - 232 p.

17. Christianity and morality: collection of scientific works. Ternopil: Ukrmedkniga, 2001. - 155 p.

18. Christian values: history and view in the third millennium: collection of scientific notes of the National University of "Ostroh Academy". Ostroh: Department of "AO", 2002. Vol. VI. - 544 p.

19. Yarosh K.N. Modern problems of moral education. Kharkiv, 1993. - 163 p. 